\title{
religion gender
}

Vol. 4, no. 1 (2014), 46-48 | URN:NBN:NL:UI:10-1-114497

\section{Review of Yvonne Maria Werner (ed.), Christian Masculinity: Men and Religion in Northern Europe in the 19th and 20th Centuries (KADOC-Studies on Religion, Culture and Society), Leuven: Leuven University Press 2011, 322 pp., ISBN 978-90-5867-873-7}

\author{
By Stephen B. Boyd, Wake Forest University, USA
}

Yvonne Maria Werner edited this volume of essays produced by participants and collaborators of the interdisciplinary research project - Christian manliness: a paradox of modernity - hosted at the University of Lund, from 2004 to 2010. The bulk of the essays are by Swedish scholars, joined also by colleagues from Belgium, Scotland, Germany, the Netherlands and Denmark. The goal of the project was to examine the relationship between Christianity and masculinity 1840-1940 - a period 'marked by the emergence' and decline of 'the liberal-bourgeois gender discourse' in which Christian ideals of 'humility, selfabnegation and piety' were defined as female qualities. The project tracked how that discourse 'affected the construction of Christian manhood and how this was reflected in men's lives' (2011: 10). Among the themes addressed and sources adduced included ideals of manliness, male religiosity, male missionary and reform activity, the image of Christian masculinity in literature, and wider theological and ideological perspectives.

The authors critically engage the theory of the feminisation of European Christianity, which has become a 'master narrative within modern research on religion and gender' (2011: 8). The theory posits that, though men traditionally played a dominant role in ecclesiastical affairs, from the middle of the nineteenth liberal, middle-class circles accepted the notion that Christian faith and religious practice was a private matter, associated with women and an increasingly delineated private sphere. Belief in science and social progress then became the 'normative guideline' for the public life - the proper sphere for men. According to this theory, religious commitment increased among women and

This work is licensed under a Creative Commons Attribution License (3.0)

Religion and Gender | ISSN: 1878-5417 | www.religionandgender.org | Igitur publishing 
religious 'attitudes, symbols, and practices were discursively feminized', while many men distanced themselves from the churches and religion. Thus, Christian manliness, as the subtitle of the research project indicates became a modern paradox. Secular worldviews began to dominate the public sphere weakening the tie between church and state and undermining the role of Christianity in the political and social order. Due to the influence of the feminisation theory, Werner claims that, 'while women's history has increasingly heeded the role of religion, religious issues have until recently been overlooked in the increasingly popular field of men's history' (2011: 8).

While acknowledging the over-representation of men in liberal, anti-clerical and socialist circles, Werner points out that these circles constituted only a minority of the population and that Christianity in its confessional, denominational forms 'continued to serve as the normative basis of society', contributing to the construction of nationalist identities. Consequently, the Research Project Group focused on the following questions: Was religion predominantly seen as a female concern? What were the outlets for male religiosity? How does one explain the large numbers of men who were committed to the church and Christian faith?

Werner locates this project within the 'growing field of men's studies' and cites the gender theories of Pierre Bourdieu and R.W. Connell as inspiration. By men's studies, she refers to a tradition of research, 'originally closely connected to feminist-oriented women's studies', that often focuses on 'ideals of manhood and the construction of masculinity'. Claiming that both fields assume that men exercise 'true power', she states that most men's studies research, including the book's essays, deal with 'homosocial relations between men and groups of men' (2011: 10). From Bourdieu's work, Werner cites his understanding that manhood is construed in competition between men in public spaces, with women playing a marginal role, but important role as onlooker. Of particular note, she lifts up Connell's theory of 'hegemonic masculinity' and its 'dialectic interplay' - alliance, dominance, subordination, and stigmatisation. Both, she notes, see male dominance over women asserted by 'symbolic violence' embedded in the social order, evidently most clearly in the religious sphere (2011: 12).

The working group posits the general hypothesis that 'church mobilization and Christian confessionalism were a strategy used by the churches to counteract the secularization of society and the feminization of religion, and to restore and reinforce male domination in the religious sphere.' Following historian Wolfgang Schmale, this hypothesis sees liberal-bourgeois discourse of masculinity, with ideals such as self-control, endurance, rationality, patriotism, heterosexuality, and physical beauty, as having been integrated into church culture - often fused with notions of nationhood - as a counterbalance to the 'effeminate' image of religious practice. This re-masculinisation offered Christian men an 'arena where male virtues and powers could be used for religious purposes' (2011: 13).

Following an introductory section on theoretical perspectives (Olaf Blaschke and Callum G. Brown) authors test the hypothesis by surveying particular aspects of the ideals of Christian manhood, missionary masculinity, nurturing Christian men, and examples of transgressing gender boundaries in the contexts of Sweden, Denmark, Norway, Belgium, the Netherlands, and China.

Werner reports several common findings of the studies presented. First, confessionally grounded social and missionary engagement constituted the main 
components of notions of Christian masculinity. The essays of Tine Van Osselaer and Alexander Maurits; Anna Prestjan, Erik Sidenvall, and Elin Malmer delineate particular arenas of that engagement. Second, there existed a widespread, concerted attempt to re-code classical Christian virtues, such as humility, obedience, and self-sacrifice - that had been gendered feminine in the dominant discourse - as contemporary male values and, by doing so, harnessing the masculine combative spirit to Christian purposes. Olaf Blaschke, David Tjeder, Werner, Sidenvall, and Malmer contribute essay illustrative of these attempts. Third, those classical Christian virtues played a more central role in Catholic than Protestant constructions, which were more tightly bound to bourgeois gender and nationalist ideologies. Of especial note here are the essays of Van Osselaer and Maurits, Werner, and Nanna Damsholt. Finally, not only religion, but also confessional and institutional aspects of religious identity, plays a critical role in gender constructions (cf. the essays by Anders Jarlert, Gösta Hallonsten, Damsholt, and Inger Littberger Caisou-Rousseau) (2011: 17).

These very strong essays persuasively demonstrate these findings, as well as the truth of the major hypothesis Werner proffers in the Introduction. The authors' orientation toward the 'feminisation theory' helps readers track the import of the enormous and disparate data with which the essays deal. The journey is a rewarding one as one finds oneself considering, with the aid of class, confessional, and national distinctions, the various ways men and churches negotiated the challenges and opportunities during this period of significant change. It is clear that men in religious institutions and masculine constructions, shaped by confessional interests, had more - even decisive - influences in shaping public life than the 'feminisation theory' would have it. That, as one might imagine, is not especially good news, as those Christian institutions and gender constructions often attempted to preserve the cultural hegemony of men. The final essay, Hallonsten's, 'The new Catholic feminism: Tradition and renewal in Catholic gender theology', offers the reader an opportunity to step back and consider questions about the relation of body/sex/nature and gender/social construction raised, at least in the reviewer's mind throughout the book. By opening up those questions and providing bibliography of further reading, the book closes with a felicitous opening.

Finally, the project's website (http://www.hist.lu.se/en/project/35) also identifies a number of new research questions, including: the question of the discursive and practical breakthrough of feminisation in Nordic church life; the importance of anti-Catholicism for the construction of Christian manliness in Scandinavia; and the relationship between manhood and feminism.

The project and this book reveal not only that religion played an important part in the way masculinities were shaped and performed, but also that, even after thirty years of the critical study of men and masculinities, a focus on these constructions and the ways men responded to them offers a helpful corrective to views that do not take them into account. 